\title{
Cross Sectional Study : The Relationship Between Online Learning Media with the Knowledge of Cardiopulmory Resuscition Skill of Nursing Students
}

\author{
Rismawati $^{1}$, Isna Hikmawati ${ }^{2}$ \\ ${ }^{1,2}$ Department of Health, Universitas Muhammadiyah Purwokerto, Indonesia
}

\begin{abstract}
ARTICLE INFO
Article history:

DOI:

10.30595/pshms.v2i.240

Submitted:

December 6, 2021

Accepted:

January 21, 2022

Published:

January 26, 2022

Keywords:

Learning Media; Knowledge;

Cardioplumonary

Resuscitation; Online Learning

ABSTRACT

The Covid-19 pandemic has affected 215 countries in the world and colleges are demanded to hold the online learning process which becomes one of the efforts to convey knowledge about Cardioplumonary Resuscitation skill to the students. The purpose of this research was to find out the correlation between online learning media and the knowledge of Cardioplumonary Resusctation skill on Nursing Students of Universitas Muhammadiyah Purwokerto. This was descriptive correlation research with cross-sectional approach that was conducted in the Faculty of Health Science in January 2021. The samples were taken using proportional startifed random sampling technique which resulted in 38 respondents. The test that was done was the statistik chi-squere test. The results of this research showed that the most implemented learning media included Youtube with 15 respondents $(39.5 \%)$, Zoom with 13 respondents (34.2\%), and Zoom+Youtube with 10 respondents $(26.3 \%)$. The results also showed that $57.9 \%$ of the respondents had low knowledge of Cardioplumonary Resuscitation skills and $42.1 \%$ han a deep knowledge of Cardioplumonary Resuscitation skills. Meanwhile, the Chisquare test showed there was a correlation between online learning media and the knowledge of Cardioplumonary Resuscitation skills with p-value of 0.002 . Therewas a correlation between online learning media and the knowledge of Cardioplumonary Resuscitation skills among Nursing students of Universitas Muhammadiyah Purwokerto.
\end{abstract}

This work is licensed under a Creative Commons Attribution 4.0 International License.

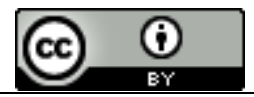

Corresponding Author:

Rismawati,

Department of Health,Universitas Muhammadiyah Purwokerto,

Soepardjo Rustam Street KM. 7, Banyumas, Indonesia

Email: risma98.124@gmail.com

\section{INTRODUCTION}

The 2019 coronavirus disease (Covid-19) outbreak has hit 215 countries in the world, posing its own challenges for educational institutions, especially universities. To fight Covid-19. The government has banned crowds, social distancing and physical distancing, wearing masks and washing hands. Through the Ministry of Education and Culture, the government has prohibited universities from conducting face-to-face (conventional) lectures and ordered them to hold lectures or learning online (Kemendikbud Dikti Circular Letter No. 1 of 2020). Universities are led to be able to organize online learning or online. [1]

Not a few universities are quick to respond to government instructions, there are around 65 universities in Indonesia that have implemented online learning in anticipation of the spread of Covid-19. [2] Jamaluddin, D., Ratnasih, T, Gunawan, H., E. said that online learning has its own strengths, challenges and obstacles. [3] Therefore, face-to-face learning that gathers many students in the classroom is reviewed for its implementation. Lectures must be held with scenarios that are able to prevent physical contact between students and lecturers and students and students. [4] According to Almarzooq in online learning, namely doing learning using internet facilities ranging from zoom meetings, google classroom and others. [5] 
Everything is done so that learning can still be carried out and students get their right to learn from teaching. Schools must be able to facilitate their students to be able to get their right, namely to get education from their teachers.

Research on the use of online lecture learning technology conducted by Agus Kusnayat (2020) shows that around $59.5 \%$ of students object to assignments given by lecturers and about $60 \%$ of students feel stressed. If this is allowed to continue, it will be fatal in the psychological development of students, because 92\% of students prefer face-to-face lectures in class compared to online lectures. Selamet Riadi's findings (2020) show that there is no internet access in student residences as much as $36 \%$, and the main obstacle for students in online lectures is the difficulty in understanding the material, which is as much as $66 \%$.

Based on the results of the evaluation of the Ministry of Education and Culture together with the task force for the acceleration of handling Covid-19, it was found that online learning turned out to have many obstacles. The students expressed complaints during online learning, students had difficulty in understanding the lecture material. Assignment problems also sometimes affect student workloads, such as assignments that are too piled up and the schedule for submitting assignments is very short. Many methods from the lecturers themselves cannot be applied online, for example clinical skills that usually use laboratory equipment. [6]

Based on a preliminary survey conducted at the Muhammadiyah University of Purwokerto to 22 undergraduate nursing students with the result that $81.8 \%$ said online lectures were not fun, $90.9 \%$ assignments given by lecturers were burdensome, internet facilities were inadequate $68.2 \%$. Learning lab skills using online media is not effective $22.7 \%$ because lab skills should be carried out in the laboratory using tools and materials according to procedures and accompanied by experts (lecturers assistants). Meanwhile, during this pandemic, students only get learning using online media, one of which is the Emergency Nursing (KGD) course. in the CPR (Cardiopulmonary Resuscitation) skill lab, students said they learned to use makeshift tools and were confused whether they already knew the skill material properly or not. Students also said that their GPA decreased when they studied online.

\section{RESEARCH METHOD}

This research is quantitative research using correlation description design with cross sectional approach. The study was conducted at the Faculty of Health Sciences, University of Muhammadiyah Purwokerto which was conducted in January 2021. The sample in this study used the proportional statified random sampling technique with 38 respondents. The test used is the correlation test.

\section{RESULTS AND DISCUSSION}

1. Characteristics of responden ( gender, age, and place of residence) on nursing studens of Universitas Muhammadiyah Purwokerto.

Table 1.1 Characteristics by gender and place of residence

\begin{tabular}{|c|c|c|}
\hline $\begin{array}{c}\text { Respondent } \\
\text { characteristics }\end{array}$ & Frequency & Percentage $(\%)$ \\
\hline \multicolumn{3}{|l|}{ Gender } \\
\hline Female & 29 & 73.3 \\
\hline Male & 9 & 23.7 \\
\hline Total & 38 & 100.0 \\
\hline \multicolumn{3}{|l|}{ Residence } \\
\hline Easy internet signal & 19 & 50.0 \\
\hline Difficult internet signal & 19 & 50.0 \\
\hline Total & 38 & 100.0 \\
\hline \multicolumn{3}{|c|}{ Table 1.2 Characteristics by age } \\
\hline $\begin{array}{l}\text { Characteristics } \\
\text { respondent }\end{array}$ & Mean+SD & Mean-Max \\
\hline Age & $20.42+0.722$ & $19-22$ \\
\hline
\end{tabular}

Shows the results of most of the respondents being female as many as 29 respondents $(73.3 \%)$ and male with a total of 9 respondents $(23.7 \%)$ and the area of residence with easy signals and difficult signals turns out to have the same number of 19 respondents. (50\%). Table 2 shows that the average age of the respondents is 20.42 years with a standard deviation of 0.722 with a minimum of 19 yearsand a maximum of 22 years. 
2. Overview of learning media on nursing studens of Universitas Muhammadiyah Purwokerto

\begin{tabular}{lll} 
& Table 4.3 description of learning media \\
\hline Learning Media & $\mathrm{F}$ & $\%$ \\
\hline Zoom & 13 & 34.2 \\
YouTube & 15 & 39.5 \\
Zoom+YouTube & 10 & 26.3 \\
\hline Total & $\mathbf{3 8}$ & $\mathbf{1 0 0 . 0}$ \\
\hline
\end{tabular}

Based on table 4.3, it can be seen that the respondents who use Zoom learning media are 13 respondents (34.2\%), YouTube media are 15 respondents $(39.5 \%)$ and 10 are usingZoom+YouTuberespondents $(26.3 \%)$.

3. Description of knowledge of Cardiopulmonary Resuscitation (CPR) skills in online learning on nursing studens of Universitas Muhammadiyah Purwokerto

Table 4.4 overview of knowledge of CPR skills

\begin{tabular}{lccc} 
& $\begin{array}{c}\text { Skill knowledge } \\
\text { CPR }\end{array}$ & F & $\%$ \\
\hline Low & & 22 & 57.9 \\
Tall & 16 & 42.1 \\
\hline Total & & $\mathbf{3 8}$ & $\mathbf{1 0 0 . 0}$ \\
\hline
\end{tabular}

Based on table 4.4 , it can be seen that respondents who have low knowledge of CPR skills (57.9\%), andrespondentswhohavehighknowledgeof CPR skills (42.1\%).

4. The relationship between learning media and knowledge of cardiopulmonary resuscitation (CPR) skills in online learning on nursing studens of Universitas Muhammadiyah Purwokerto

Table 4.5 the relationship of learning media with knowledge of CPR skills

\begin{tabular}{|c|c|c|c|c|c|c|c|}
\hline \multirow{3}{*}{$\begin{array}{l}\text { Media } \\
\text { learning }\end{array}$} & \multicolumn{6}{|c|}{ Knowledge of CPR skills } & \multirow{3}{*}{$P$-value } \\
\hline & \multicolumn{2}{|c|}{$\underline{\text { Low }}$} & \multicolumn{2}{|c|}{ Tall } & \multicolumn{2}{|c|}{ Total } & \\
\hline & $\mathrm{F}$ & $\%$ & $\mathrm{~F}$ & $\%$ & $\mathrm{~F}$ & $\%$ & \\
\hline Zoom & 12 & 92.3 & 1 & 7.7 & 13 & 100.0 & 0.002 \\
\hline YouTube & 8 & 53.3 & 7 & 46.7 & 15 & 100.0 & \\
\hline Zoom+YouTube & & 2 & 20.0 & 8 & 80.0 & 10 & 100.0 \\
\hline
\end{tabular}

Based on table 4.5 it can be explained that respondents who use Zoom learning media have low knowledge of CPR skills as many as 12 respondents $(92.3 \%)$, and those who have high knowledge are 1 respondent $(7.7 \%)$. Respondents who use the YouTube learning media have low knowledge of CPR skills as many as 8 respondents $(53.3 \%)$, and have high knowledge as many as 7 respondents $(46.7 \%)$. And respondents who use Zoom+YouTube learning media have low knowledge of 2 people $(20.0 \%)$ and have high knowledge of 8 respondents $(80 \%)$. The results of the Chi Square data analysis test obtained a significant value of $p$-value $=0.002(<\alpha=0.05)$. This can be interpreted that statistically there is a relationship between learning media and knowledge of Cardiopulmonary Resuscitation (CPR) skills. 
1. Characteristics of responden (gender, age, and place of residence) on nursing studens of Universitas Muhammadiyah Purwokerto.

Based on the results of the study, it showed that female respondents were more dominant, namely 29 respondents $(73.3 \%)$ of the total 38 respondents. This is because it has become a phenomenon that nursing students are more dominated by women, for example in the S1 Nursing Study Program at Muhammadiyah University of Purwokerto with a total of 928 students, 201 being male and 727 female. 288 students, 226 are female and the remaining 62 are male. This has proven that women dominate, because women have great freedom to pursue higher education before marriage.

According to the Ministry of Education and Culture (Kemendikbud) recorded the number of students at universities in Indonesia in 2019 it turned out that the number of women was more than that of men.1,561,326 people, while the number of men is 1,364,306 people. [7] The resultsofthis study are in line with the results of Lestari's research with 191 female respondents (92.3\%). [8] In Ngirarum's research of the 33 respondents, 21 respondents (63.6\%) were female and 12 male respondents (936.4\%). [9] The results of the study are supported by the results of Yunanto's research showing that there is a relationship between gender and the level of knowledge of nursing students on CPR knowledge, because female respondents are more likely to study hard and have the motivation to want to know more about something they do not understand. [10]

Based on the results of the study, the average age of the respondents was 20.42 with a standard deviation of 0.722 , with a minimum age of 19 years and a maximum age of 22 years. At the age of 19 years to 20 years, including the age of late adolescence, where they have experienced puberty and cognitive thinking reaches its peak in abstract thinking abilities. The meaning of abstract thinking is that they are no longer limited to reality and actual, meaning they think further ahead.

According toNototmodjo age affects a person's knowledge of something, namely knowledge of CPR skills. [11] A person's perception and mindset can be influenced by a person's age. In accordance with the theory above, it can be concluded that the older a person eats, the more knowledge he gains. They will know more about something and will also be able to increase the irintellectual abilities.

These results are in line with the results of research by Rachmawaty with the results that the respondent's age is at least 19 years and the maximum age is 22 years. [12] Widyarani with the results showing that the minimum age is 20 years and the maximum age is 26 years with an average age of 22.78 showing an increased level of cognitive ability based on the age of the respondent. [13]

Based on the results of the research, the residences of respondents who have easy internet signal access and those who have difficult internet signal access have the same value, namely $50 \%$. The increasing world of technology at this time, many places to live in the interior or the countryside have been installed with wifi and other internet access. Because internet access can determine whether respondents can access learning materials or not. When respondents can access the internet easily, they can immediately learn the material that has been provided and their knowledge will increase.

The internet isonepartof information and communication technology, a network that connects cellphones or computers using the global standard transmission control (TCP) as an exchange protocol, this internet gets the convenience of exchanging information and communicating internet transformation from wired networks, wireless networks. andsatellites.[15] So with technology, information and communication can be done directly eventhough we are in a very far away place with the person with whom we exchange information and communication.

This research is in line with the results of Rosdiyani's research in Wangun Cimuruy village which is located in the highlands which previously did not have internet access, now they have normal internet access by utilizing the wifi network. [19] So that students or students who are in the village can access online learning during the Covid-19 pandemic. It is hoped that the community or students can also increase their knowledge and get positive information. Meanwhile, research conducted by Utami (2020) said that internet signals were difficult and expensive quotas became obstacles in the learning process, resulting in students not being able to fully understand the material and their knowledge decreasing.

2. Overview of learning media on nursing studens of Universitas Muhammadiyah Purwokerto

The results showed that the most widely used learning media was YouTube as many as 15 respondents (39.5\%). This is because students can access YouTube media at any time without a set 
time limit, students also say that submitting using YouTube is easier to understand, and with YouTube, students can download the videos provided, thus saving more internet quota. The Zoom learning media also has a second large number of users, namely 13 respondents $(34.2 \%)$, students said they simply used Zoom, because when Zooming the lecturer would see whether students were present in lectures or not, so they imagined that they needed to enter Zoom even though they didn't pay attention. the teacher won't know. Students who use Zoom and YouTube are as many as 10 respondents, feel less, because if they only rely on Zoom with the time limit provided they feel it is not enough, so they also learn to use YouTube because it is more relaxed and if they don't understand they will watch it several times.

Learning media are tools used to convey messages from sender to recipient, so that recipients gain new knowledge, experience and insights according to Arsyad. [14] Learning media should be able to convey all the messages they want to convey and students can access all material in several media, because each media used has a different delivery. In delivery using media, it should be conveyed clearly and briefly, using animation or pictures so that students are not bored in learning.

Yasni Alami explained that the learning media used such as YouTube, WhatsApp, Google classroom, Zoom can be an alternative solution in learning, for the sake of continuing learning in every education, then it can increase student knowledge. [25] Zoom is a learning media using video, with zoom we can communicate directly with anyone and any where by using video and YouTube is a video sharing website that can be used to upload, watch and share videos. In this era of distance learning, YouTube plays a very important role in the learning process, because learning that has practical theory can be a solution for delivering material using video.

Nadeak in his research said that online media is an alternative learning during this pandemic, because students can access lectures anywhere. [12] The media used include Google Class, Edmodo, Schoology, WhatsApp, Facebook, YouTube and others. Students who access learning from various types of media with different knowledge will increase.

3. Description of knowledge of Cardiopulmonary Resuscitation (CPR) skills in online learning on nursing studens of Universitas Muhammadiyah Purwokerto

The results showed that most of the respondents had low knowledge of cardiopulmonary resuscitation (CPR) skills, as many as 22 respondents $(57.9 \%)$. This is because they do not understand the material that is given because usually the material is given directly but because of the pandemic period all the material must be given online, and most students feel lazy to study the material provided, some students also said that due to the many demands of assignments many with short work time leaving them stuck and no time for additional study. Knowledge of cardiopulmonary resuscitation (CPR) skills is very important for nursing students, because before taking nursing actions, they must know the ways to perform these actions, Knowledge is the impression in the human mind as a result of the use of his five senses and is different from beliefs, superstitions, and false explanations. Knowledge is also interpreted as the result of human sensing or the result of someone knowing about an object through the senses it has, by itself at the time of sensing then produces knowledge. This is strongly influenced by the intensity of attention and perception of the object. [4]

Most knowledge or cognitive is a very important domain in shaping one's actions, because from experience and research it turns out that behavior based on knowledge will be better than behavior that is not based on knowledge. Knowledge is what is known about a particular object and each type of knowledge has specific characteristics regarding what, how, and for what knowledge. [14]

Knowledge is needed for psychological encouragement in growing oneself as well as for encouraging attitudes and behavior every day, so it can be said that knowledge is a stimulus toone'sactions. [16] In there search of Mc Nally et al., knowledge of CPR increased aftergiving CPR material. [26]

This is in line with the results of Alfiah's research (2014) where the majority of respondents have good knowledge of CPR, which is $82.5 \%$. While the research conducted by Yasin (2020) about knowledge of CPR with a total of 110 respondents with the result that 83 respondents $(75.5 \%)$ have a low level of knowledge of CPR knowledge. 
4. The relationship between learning media and knowledge of cardiopulmonary resuscitation (CPR) skills in online learning on nursing studens of Universitas Muhammadiyah Purwokerto

The results showed that most of the respondents using Zoom learning media, as many as 12 respondents (92.3\%) actually had low knowledge of Cardiopulmonary Resuscitation (CPR) skills. And most of the respondents who have high knowledge of Cardiopulmonary Resuscitation (CPR) actually use Zoom+YouTube media, namely 8 respondents (80\%). The results of the Chi Square correlation data analysis test obtained a significant value of $\mathrm{p}$ Value $0.002(\mathrm{p}<0.05)$. This states that there is a relationship between learning media and knowledge of Cardiopulmonary Resuscitation Skills (CPR). From my findings, if more media is used, it will increase students' knowledge, because the more media used for learning will increase their knowledge because relying solely on the explanations given by the lecturer is not enough. only use the media provided by the lecturer. For example, by searching on various social media, web and even journal literacy. In this modern era, a lot of knowledge can be obtained easily and even free of charge, as long as students take the time to study.

The media usedis not only to collect information but can also be used to acquire academic knowledge, because it allows students to develop communication to share experiences, discuss concepts, and create shared learning spaces. Lecturers can also interact with students outside the classroom boundaries. [16] Dale's triangle cone theory states that by looking at pictures and videos, the ability to remember is equalto 30\%. [4] By looking at pictures and videos, this is what makes the media equally effective in increasing knowledge. In India WhatsApp media is used mostly for sharing information, documents, presentations, texts, videos, etc. YouTube has used to be a significant one for self-study.

There are many factors that affect a person's level of knowledge, including the level of education, experience, cultural and socio-economic environment. Knowledge is needed as a psychic boost in self-growth and attitude encouragement from daily behavior, so it can be said that knowledge is a stimulus to one's actions. The problem of knowledge is very dependent on a person, he is able to develop to find out more broadly or he is satisfied with what he already knows, so seek knowledge as much as possible because knowledge has nolimits. [14]

The results of Kitchin's research with the results of media literacy or digital literacy around the world have been used in the education system, then media literacy is related to a person's level of knowledge, because if they use a variety of different media literacy they will gain increased knowledge. [26] The results of this study are also supported by the results of Wardani's research that there is an effect of audio-visual learning on basic life support (BHD) knowledge. [22] As the results found by Rahagi that video media has an effect on the level of CPR knowledge. [18] With the learning method using animated video media, readers will not be bored and more quickly catch the explanation given.

\section{CONCLUSION}

Most of the respondents are female 29 respondents (73.3\%), the average age is 20.42 years with a standard deviation of 0.722 with a minimum age of 19 years and a maximum age of 22 years, and the residence of respondents who have easy internet signal access as well. Those who have access to a difficult internet signal are the same as 19 respondents $(50 \%)$. The description of learning media using Zoom media is 13 respondents (34.2\%), YouTube media is 15 respondents $(39.5 \%)$ and 10 respondents are using Zoom+YouTube $(26.3 \%)$.

The description of the knowledge of Cardiopulmonary Resuscitation (CPR) skills that have low knowledge is $57.9 \%$, and respondents who have high CPR skills knowledge are 42.1\%. There is a relationship between learning media and knowledge of Cardiopulmonary Resuscitation (CPR) skills The results of this study are expected to be a reference for institutions to provide more appropriate learning so that studensts do not feel bored in the learning prosess. For example, in delivering material using animation or pictures, not only using written words. And the explanation of the material on the PPT can use audio visual. Students should be able to access all the media provided by the lecturer, and be able to learn independently by using other media, so that students knowledge and insight can increase.

\section{Acknowledgments}

Thank you to Allah SWT, both parents and all comrades in arms who have helped from beginning to end 


\section{REFERENCES}

[1] Firman, F., \& Rahayu, S, "Pembelajaran Online di tengah pandemi Covid-19", 2020.

[2] CNN Indonesia. (n.d.). 65 Kampus Kuliah dari Rumah, Sultan Yogya Ragukan Efektivitas.Retrieved from https://www.cnnindonesia.com/nasional/2020031610707-20-483756/65-kampus-kuliah-darirumah-sultan-yogya-ragukan-efektivitas

[3] Jamaluddin, D., Ratnasih, T., Gunawan, H., \& Paujiah, E, "Pembelajaran Daring Masa Pandemi Covid-19 pada Calon Guru: Hambatan, Solusi dan Proyeksi". LP2M .jantung paru pada smartphone. Jurnal Ilmiah Permas. Volum 1 No 1. Halaman 97-102 ISSN : 2540-7937, 2020

[4] Barus, E. B., "Pengetahuan dan Sikap Remaja Jalanan tentang Kesehatan Brog dan Gall”, 1983. Education research an introducation, 4 th end, long man inc, 2011.

[5] Almarzooq, Z. I., Lopes, M., \& Kochar, A, Virtual Learning During The COVID-19 Pandemic. Journal of the American College of Cardiology, 75(20), 26352638, 2020.

[6] Tribun Jateng. Apa Dampak Terlalu lama Kuliah Online Karena Wabah Virus Corona?Ini kata Psikologi. Retrives.From https://jatneg.tribunnews.com/2020/05/08apa-dampak-terlalu-lama-kuliahonline-karena-wabah-virus-corona-ini-kata-psikolog?page=all

[7] Ihsan, Danang Nur, Mahasiswa Indonesia didominasi perempuan teramsuk di 5 Universitas Negeri ngetop. Solopos.com, Indonesia Jurnal of Educational Science (IJES), 2(2), 81-89. ISSN 2201, 2020.

[8] Lestari. E.D., \& Setianingsih, "Peningkatan pengetahuan orang awam tentang penanganan out hospital cardiac arrest melalui aplication resusitasi

mahasiswa keperawatan Soedirman”, The soedirman journal of nursing volume12, No 3 November 2017, 2020

[9] Ngirarung, Shinta A.A., Mulyadi, \&Malara, R.T, "Pengaruh simulasi tindakan resusitasi jantung paru (RJP) terhadap tingkat motivasi siswa menolong korban henti jantung di SMA 9 Binsun Manado", E-jurnal keperawatan(e- kp) vol.5 nomor 1, februari 2017, 2017.

Kitchin,R,Etika kota cerdas. Brainstorming RTC, https://www.rte.ie/brainstorm/2019/0425/1045602-etik-kota-pintar/, 2019.

[10] Yunanto. Rismawan.A., Wihastusi. T.A., dan Rachmawati. S.D., 2017, "Perbandingan pelatihan RJP dengan mobil application dan simulasi terhadap pengetahuan dan keterampilan melakukan RJP".

Nursingl line Journal. Vol.2 November 2017:183-194, 2017

[11] Notoatmodjo, S., "Ilmu Perilaku Kesehatan. Jakarta : Rineka Cipta.

Persaud, C. 2019. Apa yang perlu diketahui pendidik. Pucuk topik. https://tophat.com/blog/pedagogy/, 2010.

[12] Rachmawaty, Shella., "Gambaran tingkat pengetahuan mahasiswa kesehatan dan mahasiswa non kesehatan Universitas Indonesia tentang teknik resusitasi jantung paru (RJP) pada dewasa". Univeritas Indonesia, 2012.

[13] Widyarani, Linda., "Analisis pengaruh pelatihan resusitasi jantung paru (rjp) dewasa terhadap retensi pengetahuan dan keterampilan RJP”, 2017.

[14] Arsyad, Azhar., Media Pembelajaran. Jakarta : Raja Grafindo persada, 2013.

[15] Priantama, R., "Efektivitas wifi dalam menunjang proses pendidikan bagi lembaga perguruan tinggi (Studi kasus terhadap mahasiswa pengguna di lingkungan Universitas Kuningan)", jurnal clund informasion, Vol 1 No ISSN 2527-5224, 2017.

[16] Proverawati, A., \& Misaroh, S., "Menarche: Menstruasi Pertama Penuh Makna”. Yogyakarta: Nuha Medika, 2009.

[17] Alfiah, "Hubungan pengetahuan dengan keterampilan perawat dalam melakukan RJP pada pasien cardiac arest di ruang perawatan RSUD Taman Husada Bontang”, 2014.

[18] Rahagi, Resi dan Anggrasari, Anggun P., "Vidio animasi resusitasi jantung paru untuk meningkatkan pengetahuan dan sikap anak usia sekolah". ISSN 2615-3502. Http://ejurnal.binawakya.pr.id/index.php/MBI

[19] Rosdiyani, Telly dan Setiawan, N., "Pemasangan jaringan internet berbasis wireless fidelity (wifi) di kampung Wangun Cipurut", Jurnal abdi karya Volume 2 No,2 Oktober 2020 P-ISSN 268-6447, EISSN2715-6650, 2020.

[20] Reproduksi di Kota Medan Tahun 2011. Karya Tulis Ilmiah Program D-IV Bidan Pendidik Fakultas Keperawatan Universitas Sumatera Utara, 2021.

[21] Utami, Etika W., "Kendala dan peran orang tua dalam pembelajaran daring pada masa pandemi Covid-19". Prosiding seminar nasional pascasarjana UNNES, ISSN2686-6404, 2020.

[22] Wardani, Endang K., Upoyo, Setyo Arif \& Alvian, G.N., "Efektifitas pembelajaran mandiri audiovisual dan booklet bantuan hidup dasar (BHD) terhadap pengetahuan dan keterampilan perawat 
di RSUD Wonosari 2020”. Jurnal of Bionursing. Vol 2, No.3, 183-189, 2020.

[23] Nadeak, Bernadetha, "Efektifitas pembelajaran jarak jauh menggunakan media sosial selama periode pandemi covid-19”. Jurnal interansioanl sains dan teknologi lanjut. Vol.29,n07,(2020), hlm. 17641772.New York, 2019

[24] Yasin, DudellaD.f., Ahsan \& Rachmawati, S.D., "Pengetahuan remaja tentang resusitasi jantung paru berhubungan dengan efikasi diri remaja di SMK N 2 Singosari Malang”. Jurnal ilmiah ilmu kesehatan vol 8, No.1, 202, hal 116-126, 2020.

[25] Yasmi, Alami.,"Media pembelajaran daring". Volume 02, nomor 1, tahun 2020, 2020.

[26] McNally, B., Robb, R., Mehta, M., et al, Out-ofHospital Cardiac Arrest Surveillance - Cardiac Arres Registry to Enhance Survival (CARES), United States, 2011. 